\title{
Evaluasi Pengadaan Tanah Skala Kecil dengan dan tanpa Penetapan Lokasi di Kabupaten Sleman
}

\author{
Wenny Yolanda Ratna Sari, Priyo Katon Prasetyo ${ }^{2 *}$, Sudibyanung ${ }^{3}$ \\ ${ }^{1}$ Kantor Wilayah Badan Pertanahan Nasional Provinsi Sumatera Selatan, JI. POM IX Kampus No.1296, Kota Palembang \\ ${ }^{2}$ Sekolah Tinggi Pertanahan Nasional, Jl. Tata Bumi No. 5 Banyuraden, Yogyakarta \\ ${ }^{3}$ Sekolah Tinggi Pertanahan Nasional, JI. Tata Bumi No. 5 Banyuraden, Yogyakarta \\ * Korespondensi: email: priyokatonprasetyo@gmail.com
}

\begin{tabular}{|c|c|}
\hline ARTICLE INFO & ABSTRACT \\
\hline Keywords : & Land availability is the great significant part in infrastructure development. To \\
\hline Land Acquisition, Small Scale & support the land availability, the government pursues a program called land \\
\hline Land Acquisition, & acquisition. Land acquisition is regulated in Law Number 2 of 2012 and \\
\hline Determination of Land & Government Regulation Number 71 of 2012. Based on Government Regulation \\
\hline Acquisition Locations & $\begin{array}{l}\text { Number } 40 \text { of 2014, land acquisition is divided into two, including large scale } \\
\text { with an area of more than } 5 \text { hectares and small scale based with an area of less } \\
\text { than } 5 \text { hectares. Small-scale land acquisition is further regulated in Presidential }\end{array}$ \\
\hline Received: April 29, 2021 & Regulation Number 148 of 2015 Article 121 paragraph (3) which does not \\
\hline Reviewed: April 29, 2021 & require a determination of location. The purpose of this study was to determine \\
\hline Accepted: October 30, 2021 & $\begin{array}{l}\text { the implementation process as well as the advantages and disadvantages of } \\
\text { small-scale land acquisition with and without location determination in Sleman } \\
\text { Regency. This research used a qualitative method with a descriptive approach. } \\
\text { The results of this research showed that the implementation of land acquisition } \\
\text { with determination of location has advantages (4) and weaknesses (6) while } \\
\text { land acquisition without determination of location has advantages (6) and } \\
\text { disadvantages (4). }\end{array}$ \\
\hline
\end{tabular}

INFO ARTIKEL

\section{Kata Kunci:}

Pengadaan Tanah, Pengadaan

Tanah Skala Kecil, Penetapan

Lokasi Pengadaan Tanah.

\section{How To Cite :}

Sari, W. Y.R., Prasetyo, P. K., Sudibyanung. (2021). Evaluasi Pengadaan Tanah Skala Kecil dengan dan Tanpa Penetapan Lokasi Di Kabupaten Sleman. Marcapada: Jurnal Kebijakan Pertanahan, 1(1), 61-75

\section{ABSTRAK}

Ketersediaan tanah merupakah hal yang paling penting dalam pembangunan infrastruktur. Untuk menunjang ketersediaan tanah, pemerintah mengupayakan program yang disebut dengan pengadaan tanah. Pengadaan tanah diatur dalam UU Nomor 2 Tahun 2012 dan PP Nomor 71 Tahun 2012. Berdasarkan PP Nomor 40 Tahun 2014, pengadaan tanah dibagi menjadi dua yaitu skala besar dengan luas lebih dari 5 hektar dan skala kecil dengan luas kurang dari 5 hektar. Pengadaan tanah skala kecil diatur lebih lanjut dalam Perpres Nomor 148 Tahun 2015 Pasal 121 ayat (3) yaitu tidak memerlukan penetapan lokasi. Tujuan penelitian ini adalah untuk mengetahui proses pelaksanaan serta kelebihan dan kelemahan pengadaan tanah skala kecil dengan dan tanpa penetapan lokasi di Kabupaten Sleman. Penelitian ini menggunakan metode kualitatif dengan pendekatan deskriptif. Hasil penelitian ini menunjukkan pelaksanaan pengadaan tanah dengan penetapan lokasi memiliki kelebihan (4) dan kelemahan (6) sedangkan pengadaan tanah tanpa penetapan lokasi memiliki kelebihan (6) dan kelemahan (4). 


\section{A. Pendahuluan}

Populasi penduduk Indonesia pada September 2020 adalah sebesar 270,20 juta jiwa. Jumlah penduduk hasil Sensus Penduduk 2020 bertambah 32,56 juta jiwa dibandingkan hasil Sensus Penduduk 2010. Dengan luas daratan Indonesia sebesar 1,9 juta km2, maka kepadatan penduduk Indonesia sebanyak 141 jiwa per km2 (BPS 2020).

Perkembangan penduduk, kebutuhan perumahan permukiman, dan ketersediaan tanah bersifat dinamis, yang harus dipahami, dicermati proses perubahannya dari waktu ke waktu (Makarauw 2012). Wilayah kota cenderung memiliki jumlah penduduk yang lebih besar dibanding di wilayah pedesaan yang menyebabkan jumlah kepemilikan lahan lebih banyak di kota dibanding di desa pada luasan tertentu. Oleh sebab itu dalam kegiatan pembebasan lahan di kota lebih sulit dilakukan karena banyaknya kepentingan meski kegiatan tersebut dilakukan untuk pembangunan infrastruktur yang bermuara pada peningkatan kesejahteraan umum. Salah satu upaya pemerintah untuk menjawab hal tersebut adalah dengan pengadaan tanah untuk kepentingan umum. Menurut Edi Rohaedi, Isep H. Iksan dan Nadia Zumaro (2019) arti Pengadaan tanah mempunyai 3 unsur yaitu: (1) Kegiatan untuk mendapatkan tanah, dalam rangka pemenuhan lahan pembangunan untuk kepentingan umum; (2) Pemberian ganti rugi kepada yang terkena kegiatan pengadaan tanah; (3) Pelepasan hubungan hukum dari pemilik tanah kepada pihak lain. Kepentingan umum hanya konsep yang dapat ditetapkan kriterianya saja, dan tidak dapat dirumuskan pengertiannya. Kepentingan umum adalah konsep hukum yang kabur, hanya untuk alasan praktis konsep kepentingan umum diterapkan (Dulmuzid, Sinulingga S, , Pujangkoro S, 2019). Kepentingan umum dapat saja dikatakan untuk keperluan, kebutuhan atau kepentingan orang banyak atau tujuan sosial yang luas. Belum ada definisi yang sudah dibakukan mengenai pengertian kepentingan umum.

Menurut Undang-Undang Nomor 2 Tahun 2012 pengadaan tanah diartikan sebagai kegiatan menyediakan tanah dengan cara memberi ganti kerugian yang layak dan adil kepada pihak yang berhak. Peraturan pelaksanaan pengadaan tanah diatur dalam Peraturan Presiden Nomor 71 Tahun 2012. Selama pelaksanaannya, Peraturan Presiden Nomor 71 Tahun 2012 mengalami perubahan sebanyak empat kali yaitu Peraturan Presiden Nomor 40 Tahun 2014, Peraturan Presiden Nomor 99 Tahun 2014, Peraturan Presiden Nomor 30 Tahun 2015 dan Peraturan Presiden Nomor 148 Tahun 2015. Berdasarkan Peraturan Presiden Nomor 40 Tahun 2014, pengadaan tanah dibagi menjadi dua yaitu skala besar dengan luas lebih dari 5 hektar dan skala kecil dengan luas kurang dari 5 hektar. Pengadaan tanah skala kecil diatur lebih lanjut dalam Peraturan Presiden Nomor 148 Tahun 2015 Pasal 121 ayat (3) Pengadaan tanah untuk kepentingan umum yang luasnya tidak lebih dari lima hektar tidak memerlukan penetapan lokasi. Penetapan lokasi adalah penetapan atas lokasi pembangunan untuk kepentingan umum yang ditetapkan dengan keputusan gubernur yang dipergunakan sebagai izin pengadaan tanah, perubahan penggunaan tanah, dan peralihan hak atas tanah dalam pengadaan tanah bagi pembangunan untuk kepentingan umum.

Berdasarkan ketentuan tersebut dapat disimpulkan bahwa penetapan lokasi memiliki 3 (tiga) fungsi, yaitu: pertama, izin pengadaan tanah yang batas waktu kegiatannya 2 (dua) tahun dan dapat diperpanjang 1 (satu) tahun (untuk program strategis nasional dapat diperpanjang dua tahun); kedua, izin perubahan penggunaan tanah; ketiga, izin pemindahan hak atas tanah. Undang-undang 
Nomor 2 Tahun 2012 menempatkan penetapan lokasi sebagai starting point dalam kegiatan pengadaan tanah bagi pembangunan untuk kepentingan umum, sehingga instansi yang memerlukan tanah harus mengajukan dan memperoleh penetapan lokasi terlebih dahulu kepada gubernur untuk memperoleh tanah (Muliyawarman JW, 2018).

Beberapa studi telah mengupas mengenai pengadaan tanah skala kecil, namun studi-studi itu berkutat pada hambatan-hambatan dalam pelaksanaan pengadaan tanah skala kecil (Putri, 2017) atau faktor penghambat dan pendorong keberhasilan pengadaan tanah skala kecil (Naryana, 2020). Sementara itu, penelitian perbandingan pengadaan tanah skala kecil dengan dan tanpa menggunakan penetapan lokasi di satu daerah yang sama belum pernah dilakukan sebelumnya.

Kabupaten Sleman melakukan pengadaan tanah skala kecil dengan dan tanpa penetapan lokasi seperti pembangunan untuk jalan dan Jembatan Lemah Abang dengan luas $3.200 \mathrm{~m} 2$ dan pembangunan untuk pelebaran Jalan Padjajaran sebagai pendukung pembangunan Underpass di simpang empat Jalan Kaliurang yang luasnya kurang lebih $2.884,20 \mathrm{~m} 2$ dengan penetapan lokasi Surat Keputusan Gubernur Daerah Istimewa Yogyakarta Nomor 110/KEP/2018 tanggal 2 April 2018. Berdasarkan hal itu, sekiranya perlu dilakukan perbandingan dalam hal penetapan lokasi pada pengadaan tanah di Kabupaten Sleman, sehingga dapat diketahui pelaksanaan pengadaan tanah skala kecil dengan menggunakan penetapan lokasi dan tidak menggunakan penetapan lokasi, serta dapat mengetahui kelebihan dan kekurangan pengadaan tanah dengan menggunakan penetapan lokasi dan tidak menggunakan penetapan lokasi.

\section{B. Metode}

Penelitian ini menggunakan metode kualitatif deskriptif, dengan melakukan wawancara terstruktur untuk memperoleh informasi yang diperlukan. Pemilihan menggunakan metode penelitian deskriptif kualitatif yang bertumpu pada pengumpulan data dari hasil wawancara pada stakeholder dan orang-orang yang memiliki informasi mengenai topik penelitian. Data primer berasal dari wawancara dengan pihak yang mengetahui informasi yang diperlukan yaitu:

1. Pejabat Pembuat Komitmen Satuan Kerja Pelaksanaan Jalan Nasional Daerah Istimewa Yogyakarta Pekerjaan Umum dan Perumahan Rakyat Republik Indonesia mengenai pengadaan tanah skala kecil dengan menggunakan penetapan lokasi dalam tahap perencanaan.

2. Kepala Bagian Pelaksanaan Pembangunan Biro Administrasi Pembangunan Dinas Pertanahan dan Tata Ruang Daerah Istimewa Yogyakarta mengenai pengadaan tanah skala kecil dengan menggunakan penetapan lokasi dalam tahap persiapan.

3. Kepala Seksi Bina Pengadaan dan Penetapan Tanah Pemerintah Kantor Wilayah Badan Pertanahan Nasional Provinsi Daerah Istimewa Yogyakarta di Kota Yogyakarta mengenai pengadaan tanah skala kecil dengan menggunakan penetapan lokasi dalam tahap pelaksanaan.

4. Kepala Bidang Pengadaan Tanah dan Pengurusan Hak-Hak Atas Tanah Pemerintah Daerah Kabupaten Sleman mengenai proses kegiatan pengadaan tanah skala kecil tanpa penetapan lokasi. 
Data sekunder yang diambil adalah bukti penetapan lokasi berupa surat keputusan lokasi dan juga meliputi peraturan perundang-undangan yang mengatur urusan pengadaan tanah dan pemerintah daerah. Data primer diambil dengan menggunakan metode wawancara dan dianalisis menggunakan metode matching dan SWOT agar diperoleh kelebihan dan kekurangan pengadaan tanah skala kecil dengan atau tanpa penetapan lokasi.

\section{Pelaksanaan Pengadaan Tanah Skala Kecil bagi Pembangunan untuk Kepentingan Umum dengan Menggunakan Penetapan Lokasi}

Pengadaan tanah untuk pelebaran Jalan Padjajaran sebagai pendukung pembangunan Underpass di Simpang Empat Jalan Kaliurang di dalam Keputusan Gubernur Daerah Istimewa Yogyakarta Nomor: 110/KEP/2018 tanggal 2 April 2018 tentang Penetapan Lokasi Pembangunan untuk Pelebaran Jalan Padjajaran sebagai Pendukung Pembangunan Underpass di Simpang Empat Jalan Kaliurang Daerah Istimewa Yogyakarta dengan luas +- 2.884 m2 (kurang lebih dua ribu delapan ratus delapan puluh empat meter persegi). Dengan adanya Surat Keputusan Gubernur tentang penetapan lokasi yang dikeluarkan agar mempermudah dan mempercepat pelaksanaan pengadaan tanah. Kegiatan pengadaan tanah bagi pembangunan untuk kepentingan umum mempunyai tahapan-tahapan dalam pelaksanaannya. Adapun tahapan-tahapan pelaksanaan dalam pengadaan tanah tersebut yaitu penyiapan pelaksanaan, pembentukan satgas, pengumuman hasil inventarisasi dan identifikasi, penilaian ganti rugi, pelaksanaan musyawarah, pengajuan keberatan pengadilan, pembayaran ganti kerugian dan pelepasan hak atas tanah.

Pelaksanaan pengadaan tanah dilaksanakan oleh Kepala Kantor Wilayah Badan Pertanahan Nasional (Kakanwil BPN). Ketua pelaksana pengadaan tanah selanjutnya membentuk satuan tugas (satgas) untuk melaksanakan inventarisasi dan identifikasi data fisik dan data yuridis bidang-bidang tanah yang menjadi objek pembangunan untuk pelebaran Jalan Padjajaran sebagai pendukung pembangunan Underpass di simpang empat Jalan Kaliurang Daerah Istimewa Yogyakarta. Satgas A bertugas mengumpulkan data fisik penguasaan, pemilikan, penggunaan dan pemanfaatan tanah. Satgas B bertugas mengumpulkan data pihak yang berhak dan objek pengadaan tanah. Hasil inventarisasi dan identifikasi yang dilakukan satgas A dituangkan dalam bentuk peta bidang tanah. Hasil inventarisasi dan identifikasi yang dilakukan satgas B dituangkan dalam bentuk daftar nominatif.

Hasil inventarisasi dan identifikasi bidang tanah objek pembangunan untuk Pelebaran Jalan Padjajaran sebagai Pendukung Pembangunan Underpass di Simpang Empat Jalan Kaliurang Daerah Istimewa Yogyakarta selanjutnya dibuatkan peta bidang dan daftar nominatif yang dijadikan sebagai bahan pengumuman di masing-masing desa. Pengumuman di Desa Sinduadi Kecamatan Mlati dan Desa Caturtunggal Kecamatan Depok Kabupaten Sleman dilakukan serentak dimulai pada tanggal 28 Mei 2018 yang tertuang dalam Pengumuman Hasil Inventarisasi dan Identifikasi Peta Bidang Tanah dan Daftar Nominatif Pengadaan Tanah pembangunan untuk Pelebaran Jalan Padjajaran sebagai Pendukung Pembangunan Underpass di simpang empat Jalan Kaliurang di Desa SinduadiKecamatan Mlati dan Desa Caturtunggal-Kecamatan Depok, Kabupaten Sleman Nomor: 104/MumPPT/V/2018. 
Tabel 1. Hasil Inventarisasi dan Identifikasi oleh Satgas

\begin{tabular}{lllc}
\hline No. & \multicolumn{1}{c}{ Hasil } & \multicolumn{2}{c}{ Jumlah Bidang Tanah } \\
\cline { 3 - 4 } & & Sinduadi & Caturtunggal \\
\hline 1. & Bidang tanah yang bersertipikat & 16 bidang & 51 bidang \\
2. & Bidang tanah yang belum bersertipikat & 8 bidang & 19 bidang \\
Jumlah total bidang tanah yang diukur & 24 bidang & 70 bidang \\
\hline
\end{tabular}

Sumber: Hasil Olahan Data Sekunder 2020

Berdasarkan Tabel 1 di atas dapat diketahui bahwa di Desa Sinduadi yang menjadi objek pembangunan jalan tol sebanyak 25 bidang sedangkan bidang tanah di Desa Caturtunggal yang menjadi objek pembangunan jalan tol sebanyak 72 bidang. Bidang tanah di Desa Sinduadi yang menjadi objek pembangunan pelebaran Underpass Kentungan terdiri dari 16 bidang yang sudah bersertipikat dan 9 bidang yang belum bersertipikat sedangkan bidang tanah di Desa Caturtunggal yang menjadi objek pembangunan perluasan Underpass Kentungan terdiri dari 51 bidang sudah bersertipikat dan 21 bidang belum bersertipikat.

Pengumuman hasil inventarisasi dan identifikasi bidang tanah objek pembangunan perluasan Underpass Kentungan dilakukan di balai desa masing-masing selama 14 hari kerja. Adanya jangka waktu pengumuman ini memberikan kesempatan kepada masyarakat di Desa Sinduadi dan Caturtunggal untuk mengajukan sanggahan apabila terdapat keberatan terhadap hasil inventarisasi dan identifikasi yang dilakukan satgas.

Peta bidang dan daftar nominatif yang telah diumumkan digunakan oleh penilai publik untuk menentukan nilai ganti kerugian. Penilaian besar ganti kerugian bidang tanah yang dilakukan oleh penilai publik mencakup beberapa hal yaitu nilai penggantian wajar tanah, nilai bangunan, biaya tambahan (biaya pindah, biaya kontrak, dan usaha toko/sejenisnya), nilai tanam tumbuh dan kompensasi masa tunggu.

Penilai melakukan penilaian terhadap keadaan fisik dan non fisik. Kerugian non fisik dikonversi dalam bentuk uang. Setelah dilakukan proses penilaian bidang tanah di Desa Sinduadi dan Caturtunggal oleh penilai publik, hasil penilaian bidang tanah diserahkan kepada Ketua Pelaksana Pengadaan Tanah.

Pelaksana pengadaan tanah melaksanakan musyawarah penetapan ganti kerugian dengan mengundang pihak yang berhak dari Desa Sinduadi dan Caturtunggal, Instansi yang memerlukan tanah, dan instansi-instansi yang terkait. Setelah melaksanakan musyawarah, masyarakat yang setuju tanahnya ditetapkan sebagai lokasi untuk pelebaran jalan Underpass menandatangani Berita Acara Kesepakatan. Dalam pelaksanaannya, terdapat 3 bidang di Desa Caturtunggal dan 2 bidang di Desa Sinduadi yang pemiliknya tidak diketahui keberadaannya.

Besaran ganti rugi terlampir dalam berita acara kesepakatan. Pada Pasal 74 Perpres No 71 Tahun 2012 menyebutkan bahwa ganti rugi dapat diberikan dalam bentuk uang, tanah pengganti, pemukiman kembali, kepemilikan saham atau bentuk lain yang disetujui oleh para pihak. Terhadap 5 bidang yang tidak diketahui pemiliknya, maka penyimpanan uang ganti kerugian dapat dititipkan 
di Pengadilan Negeri Sleman atau konsinyasi, hal ini tertuang dalam Salinan Penetapan Pengadilan Negeri Sleman Kelas 1 A No. 1/Pdt.P Kons/2019/PN.Smn, No. 2/Pdt.P Kons/2019/PN.Smn, No. 3/Pdt.P Kons/2019/PN.Smn, No. 4/Pdt.P Kons/2019/PN.Smn dan No. 5/Pdt.P Kons/2019/PN.Smn tanggal 26 September 2019.

Setelah proses pemberian ganti rugi dilakukan, maka proses selanjutnya adalah pelepasan hak oleh pemilik tanah kepada negara. Pelepasan hak dari pemilik tanah kepada negara tersebut dilakukan di hadapan Kepala Kantor Pertanahan Kabupaten Sleman sekaligus penyerahan alat bukti kepemilikan hak atas tanah. Dengan dilepaskannya tanah tersebut oleh pemilik tanah, maka statusnya menjadi tanah negara. Tanah negara tersebut kemudian diajukan permohonan Hak Pakai oleh Kementerian Pekerjaan Umum dan Perumahan Rakyat Cq. Direktorat Jenderal Bina Marga Cq. Satuan Kerja Pelaksana Jalan Nasional Wilayah Propinsi Daerah Istimewa Yogyakarta.

\section{Pelaksanaan Pengadaan Tanah Skala Kecil bagi Pembangunan untuk Kepentingan Umum Tanpa Menggunakan Penetapan Lokasi}

Beberapa pengadaan tanah skala kecil di Kabupaten Sleman dilakukan secara langsung yaitu tanpa menggunakan penetapan lokasi sesuai dengan Peraturan Presiden Nomor 148 Tahun 2015. Sebagai contoh, daerah yang tidak menggunakan penetapan lokasi adalah pengadaan tanah penambahan lahan untuk pembangunan Jalan dan Jembatan Lemah Abang, dan pengadaan tanah untuk pelebaran Jalan Ringroad Jombor sebagai pendukung pembangunan Underpass di simpang empat Jombor Jalan Magelang.

Proses pelaksanaan pengadaan tanah ini diawali dengan Surat Permohonan Penambahan Lahan untuk Pembangunan Jalan dan Jembatan Lemah Abang dari Dinas Pekerjaan Umum, Perumahan dan Energi Sumber Daya Mineral ke Bupati Sleman Nomor 630/04089 Tanggal 10 Maret 2017 dengan luas +- $3.100 \mathrm{~m} 2$ (tiga ribu seratus meter persegi). Usulan mengenai pengadaan tanah ini telah direncanakan 1 (satu) tahun sebelum tahun anggaran dan anggaran bersumber dari APBD Kabupaten Sleman.

Tata ruang merupakan dasar dari rencana pengadaan tanah, tidak terkecuali pada pengadaan tanah yang dilaksanakan secara langsung. Surat rekomendasi kesesuaian tata ruang penambahan lahan untuk pembangunan Jalan dan Jembatan Lemah Abang yang dikeluarkan oleh Badan Koordinasi Penataan Ruang Daerah Pemerintah Kabupaten Sleman Nomor 650/042 tanggal 20 Mei 2015, telah didapatkan terlebih dahulu. Hal ini dikarenakan pengadaan tanah yang dilakukan merupakan penambahan lahan yang berarti pembangunan jalan dan jembatan Lemah Abang telah dilakukan sebelumnya.

Pelaksanaan pengadaan tanah ini tidak terlepas dari peran banyak pihak, sehingga sangat diperlukan koordinasi dengan stakeholder yang dapat menunjang kesuksesan pengadaan tanah penambahan lahan untuk pembangunan jalan dan Jembatan Lemah Abang. Para stakeholder yang dimaksud yaitu Kepala Dinas Pekerjaan Umum Perumahan dan Kawasan Permukiman Kabupaten Sleman, Kepala Dinas Perhubungan, Dinas Komunikasi dan Informasi Kabupaten Sleman, Kapolres Sleman, Kaposek Prambanan, Camat Prambanan, Pimpinan PT. PLN area DIY dan Jateng dan Pertinggal. 
Bentuk koordinasi yang dimaksud dapat dilihat berdasarkan surat dari Dinas Pekerjaan Umum, Perumahan dan Energi Sumber Daya Mineral, sebagai instansi yang memerlukan tanah, memberikan surat untuk para stakeholder mengenai informasi pelaksanaan pekerjaan pembangunan jalan dan Jembatan Lemah Abang No. 630/01123 Tanggal 23 Januari 2017. Dengan adanya surat ini selanjutnya para pihak terkait dapat melakukan koordinasi untuk menentukan langkah pelaksanaan pengadaan tanah.

Kesuksesan pelaksanaan pengadaan tanah tidak terlepas Tim Pelaksana Pengadaan tanah. Bupati Sleman mengeluarkan Keputusan No. 110.5/Kep.KDH/A/2017 tanggal 4 September 2017 tentang Tim Pelaksana Pengadaan Tanah untuk Pembangunan Jembatan Lemah Abang Desa Gayamharjo Kecamatan Prambanan yang bertugas untuk melaksanakan pengadaan tanah. Dalam surat keputusan ini juga menunjuk pelaksana utama, pelaksana penunjang, pelaksana teknis dan pembantu pelaksana teknis sebagai penanggung jawab kegiatan. Penanggung jawab kegiatan bertanggung jawab dan melaporkan hasil pelaksanaan tugas tim kepada Bupati.

Tahap berikutnya, tim pelaksana pengadaan tanah melakukan sosialisasi perihal pengadaan tanah penambahan lahan untuk pembangunan jalan dan Jembatan Lemah Abang, selanjutnya tim pelaksana dapat mengumpulkan alas hak para pemilik tanah yang terkena objek pengadaan tanah. Berkas para pemilik tanah yang terkena objek pengadaan tanah dikumpulkan untuk didaftarkan pengukuran tanah ke Kantor Pertanahan Kabupaten Sleman sehingga didapatkan peta bidang objek pengadaan tanah.

Tim pelaksana menyampaikan peta bidang tanah serta daftar nominatif ke Kantor Jasa Penilaian Publik, untuk dilakukan penilaian bidang tanah yang hasilnya berupa surat laporan hasil penilaian Nomor 066/AHDR-JOG/LHP/VIII/2017 Tanggal 23 Agustus 2017. Dengan adanya hasil penilaian terhadap 20 objek pengadaan tanah penambahan lahan untuk pembangunan jalan dan Jembatan Lemah Abang, maka tim penilai selanjutnya melakukan negosiasi ganti rugi ke para pemilik bidang tanah. Dalam proses negosiasi harga, tim pelaksana pengadaan tanah menawarkan harga di bawah harga dari hasil penilaian. Ini dilakukan agar terjadi tawar menawar yang tidak melebihi nilai yang telah ditetapkan appraisal. Negosiasi ganti rugi pada pengadaan tanah ini juga tergolong cukup lama dikarenakan, terdapat beberapa pemilik bidang tanah yang tidak sepakat dengan nilai ganti rugi yang telah ditawarkan, namun pada akhirnya pemilik bidang tanah menyetujui setelah dilakukan pendekatan oleh tim pengadaan tanah secara terus-menerus. Penerimaan ganti rugi pengadaan tanah kemudian dituangkan dalam Surat Pernyataan Penerimaan Ganti Rugi dan Penyerahan/Pelepasan Hak Atas Tanah untuk Pembangunan Jalan Pendekat (OPRIT) Jembatan Lemah Abang di Desa Gayamharjo, Kecamatan Pramabanan, Kabupaten Sleman tanggal 22 September 2017 dilegalisasi di Kantor Pertanahan Kabupaten Sleman Nomor 09/BPN/2017.

\section{E. Kelebihan dan Kelemahan Pengadaan Tanah Skala Kecil}

Dalam pengadaan tanah skala kecil memiliki kelebihan dan kelemahan proses pengadaan tanah dengan menggunakan penetapan lokasi. Kelebihannya sebagai berikut: 1) Kelebihan Dapat dilakukan konsinyasi; 2) Lokasi tidak berpindah-pindah; 3) Dokumen perencanaan yang lengkap; 4) Kelengkapan perizinan pengadaan tanah; 5) Transparansi nilai ganti rugi; 6) Nilai ganti rugi ditetapkan oleh appraisal sehingga tidak berpotensi merugikan negara. Sedangkan kelemahannya 
diantaranya: a) Waktu pelaksanaan pengadaan tanah cenderung lama; b) Waktu pembangunan cenderung lama; c) Biaya pelaksanaan pengadaan tanah besar; d) Kurangnya terjalin hubungan sosial yang baik terhadap masyarakat terkena pengadaan tanah; e) Koordinasi antar panitia pengadaan tanah yang kurang baik; f) Potensi terdapat tanah sisa; g) Kurangnya partisipasi masyarakat.

Untuk kelebihan proses pengadaan tanah tanpa menggunakan penetapan lokasi sebagai berikut: 1) Waktu pelaksanaan pengadaan tanah relatif lebih cepat; 2) Waktu pembangunan lebih cepat; Biaya pelaksanaan pengadaan tanah tidak banyak; 3) Panitia pelaksana pengadaan tanah dapat melakukan pendekatan secara personal kepada para pemilik bidang tanah; 4) Aparat desa turut mendukung proses pengadaan tanah; 5) Tidak adanya potensi terhadap tanah sisa; 6) Adanya partisipasi aktif masyarakat dalam proses pengadaan tanah. Untuk kelemahannya adalah:

a. Tidak dapat dilakukan konsinyasi.

b. Lokasi pengadaan tanah dapat berpindah-pindah.

c. Dokumen perencanaan yang tidak lengkap.

d. Perizinan yang tidak lengkap.

e. Negosiasi nilai ganti rugi berpotensi merugikan negara.

f. Tidak adanya transparansi nilai ganti rugi.

Pengadaan tanah skala kecil memerlukan sebuah metode untuk mengetahui situasi yang sedang dijalankan. Dalam penelitian ini analisis SWOT yang merupakan singkatan dari Strengths, Weaknesses, Oppurtunities, dan Threats digunakan sebagai sarana untuk mengetahui kondisi terkini pelaksanaan pengadaan tanah mengetahui kekuatan dan kelemahan dalam pelaksanaannya serta mengetahui potensi-potensi kesempatan dan ancaman dari faktor-faktor eksternal. Dalam berbagai literatur disebutkan SWOT analisis digunakan oleh berbagai organisasi untuk membantu mengidentifikasi kekuatan, kelemahan, kesempatan serta ancaman yang kemudian dapat diperoleh strategi-strategi yang diperlukan untuk meningkatkan proses-proses manajemen yang sudah ada.

\section{F. Temuan Lapangan dalam Pelaksanaan Pengadaan Tanah Skala Kecil di Kabupaten Sleman}

1. Temuan dalam Pelaksanaan Pengadaan Tanah Skala dengan dan tanpa Menggunakan Penetapan Lokasi.

Dalam pengadaan tanah skala kecil, Penetapan Lokasi dilakukan oleh Instansi yang memerlukan tanah yaitu Satuan Kerja Pelaksana Jalan Nasional Wilayah Provinsi Daerah Istimewa Yogyakarta, Dinas Pertanahan dan Tata Ruang Daerah Istimewa Yogyakarta, dan Kantor Wilayah Badan Pertanahan Nasional Provinsi Daerah Istimewa Yogyakarta. Pengumpulan data terkait dengan kebijakan-kebijakan mengenai pengadaan tanah skala kecil dengan menggunakan Penetapan lokasi difokuskan pada ketiga kantor tersebut.

Temuan dalam pengadaan tanah skala kecil dengan menggunakan penetapan lokasi di Kabupaten Sleman adalah:

1) Dokumen perencanaan menggunakan pihak ketiga.

2) Rencana anggaran biaya pengadaan tanah persiapan-pelaksanaan.

3) Izin pengadaan tanah terpenuhi.

4) Kesesuaian rencana tata ruang wilayah. 
5) Verifikasi dokumen perencanaan pengadaan tanah.

6) Konsultasi publik.

7) Penitipan ganti kerugian di pengadilan.

8) Perubahan daftar nominatif dan penilaian ulang.

9) Penilaian dan pembayaran ganti kerugian tanah sisa.

10) Sistem informasi pengadaan tanah.

11) Penetapan lokasi.

12) Waktu relatif cepat.

13) Tidak dapat dilakukan konsinyasi.

14) Lokasi pengadaan tanah yang belum pasti.

15) Nilai tanah dapat dinegosiasi.

Temuan terjadi dikarenakan sebagai berikut, dokumen perencanaan menggunakan Pihak Ketiga, hal ini dikarenakan ketidakmampuan instansi yang memerlukan tanah dalam penyusunan yang kurang lebih memuat 9 (sembilan) bagian mulai dari maksud dan tujuan pembangunan sampai pada perkiraan waktu pembangunan, hal ini hanya bisa dilakukan instansi yang memerlukan tanah dengan bekerja sama dengan instansi terkait dan lembaga lain, sebagai akibatnya adalah, daftar nominatif sementara yang terdapat dalam dokumen perencanaan tidak sesuai dengan daftar inventarisasi dan identifikasi bidang tanah. Rencana anggaran biaya pengadaan tanah persiapanpelaksanaan, tidak baik sehingga membutuhkan penyesuaian-penyesuaian dalam pelaksanaannya.

Izin pengadaan tanah terpenuhi, dimana penetapan lokasi dilakukan dalam pengadaan tanah skala kecil di Kabupaten Sleman oleh sebab itu aspek legalitas kegiatan pengadaan tanah telah terpenuhi, selain itu unsur kesesuaian dengan rencana tata ruang wilayah kabupaten dijadikan syarat agar diperolehnya penetapan lokasi dalam hal ini semua kegiatan pengadaan tanah harus mempertimbangkah hal itu. Verifikasi dokumen perencanaan pengadaan tanah dilakukan untuk Perbaikan data awal penguasaan dan pemilikan atas tanah sebagai gambaran umum status tanah karena data awal tidak menggambarkan lokasi dimana tanah berada. Kemudian pada narasi di dalam bab yang berisi kesesuaian dengan tata ruang Kabupaten Sleman.

Kegiatan konsultasi publik harus sesuai dengan asas keterbukaan yakni dalam penyampaian informasi selengkap-lengkapnya. Dalam pelaksanaannya, konsultasi publik dilakukan dengan melibatkan pihak berhak. Namun pada kegiatan konsultasi publik belum didapati kesepakatan sepenuhnya untuk memberikan persetujuan. Ketidaksetujuan tentang besaran ganti kerugian diselesaikan dengan penitipan ganti kerugian di pengadilan atau sering disebut dengan konsinyasi dalam hal ini terdapat 5 (lima) bidang tanah yang dititipkan di pengadilan, 2 (dua) bidang di Desa Sinduadi Rp.363.038.548,- dan 3 (tiga) bidang di Desa Caturtunggal Rp.425.764.264,- atas nama Suyanto, Andri Kurnianto, Dr. H. Tagop Sudarso, Syarudin Adhi Chandra dan Sukesi Mahmud.

Perubahan daftar nominatif dan penilaian ulang dilakukan dikarenakan ada bidang yang dulunya diidentifikasi dalam Daftar Nominatif sebagai tanah negara dengan luas $2 \mathrm{~m}^{2}$ yang ternyata diakui sebagai milik sdr. Biyun Zukhruf sehingga dibutuhkan penilaian ulang terhadap objek bidang tanah tersebut, berarti ada ketidak tepatan dalam melakukan kegiatan identifikasi dan verifikasi yang dilakukan oleh satgas $A$ dan $B$. 
Penilaian dan pembayaran ganti kerugian tanah sisa, kegiatan ini sebenarnya bisa dilakukan bersamaan dengan pelaksanaan pengadaan tanah tetapi dalam hal ini dilakukan tersendiri yaitu terhadap bidang tanah milik Marina dengan luas $12 \mathrm{~m} 2$ terletak diluar IPL namun menjadi satu kesatuan dengan bidang yang dilepaskan karena terdampak pengadaan tanah Underpass Jl. Kaliurang dan bidang tanah dimaksud sudah tidak layak dipergunakan lagi.

Kantor Wilayah Badan Pertanahan Nasional Provinsi DIY hingga saat ini belum menjalankan Aplikasi Sistem Informasi Pengadaan Tanah untuk menjalankan proses pengadaan tanah di Provinsi DIY. Proses pelaksanaan pengadaan tanah skala kecil tanpa menggunakan Penetapan Lokasi, dilaksanakan oleh Badan Keuangan dan Aset Daerah Kabupaten Sleman. Untuk itu pengumpulan data terkait dengan kebijakan-kebijakan mengenai pengadaan tanah skala kecil tanpa menggunakan Penetapan lokasi difokuskan pada kantor ini.

Waktu yang diperlukan relatif lebih singkat karena tidak menggunakan tahap perencanaan, tahap persiapan, tahap pelaksanaan, tahap penyerahan hasil. Prosesnya langsung antara instansi yang memerlukan tanah dengan pihak pemegang hak atas tanah. Pengadaan tanah skala kecil tanpa menggunakan penetapan lokasi tidak melalui 4 (empat) tahapan seperti perencanaan, persiapan, pelaksanaan dan pembagian hasil sehingga biaya yang diperlukan lebih sedikit. Tidak adanya penetapan lokasi dalam pengadaan tanah skala kecil ini bukan tanpa konsekuensi hukum. Tidak adanya penetapan lokasi dalam pengadaan tanah skala kecil ini mengakibatkan instansi yang memerlukan tanah tidak dapat melakukan penitipan ganti kerugian di pengadilan karena salah satu syarat yang diatur dalam Peraturan Mahkamah Agung No. 3 Tahun 2016 tentang Tata Cara Pengajuan Keberatan dan Penitipan Ganti Kerugian ke Pengadilan Negeri dalam Pengadaan Tanah Bagi Pembangunan untuk Kepentingan Umum adalah penetapan lokasi yang ditetapkan oleh gubernur atau walikota/bupati. pengadaan tanah skala kecil tanpa menggunakan penetapan lokasi mengakibatkan masyarakat yang hak atas tanahnya terkena pengadaan tanah tidak terikat untuk menyerahkan tanahnya demi kepentingan umum. Hal ini mengakibatkan, masyarakat dapat menolak pengadaan tanah yang akan dilaksanakan. Dengan demikian, bila pengadaan tanah tersebut ditolak oleh masyarakat yang tanahnya terkena pengadaan tanah, maka pelaksanaan pengadaan tanah tersebut harus dipindahkan lokasinya ke lokasi yang lain. Sesuai dengan pasal 21 Perpres No. 55 tahun 1993. Nilai tanah dapat dinegosiasikan. Pemberian ganti kerugian yang layak dalam pengadaan tanah yaitu pemberian kompensasi yang sepadan bahkan lebih maju (kehidupan yang lebih baik) kepada bekas pemilik berupa: ganti rugi terhadap hak atas tanah, bangunan, tanaman dan benda-benda lain yang berkaitan dengan tanah dan mempunyai nilai ekonomis. Pemberian tersebut lebih cepat diberikan apabila tanahnya sangat diperlukan dan tidak bisa ditunda-tunda lagi karena membahayakan kepentingan bersama dan keselamatan bersama (Sastranegara, 1997). Meskipun appraisal telah menetapkan nilai tanah obyek yang terkena pengadaan tanah, namun pada proses pelaksanaannya nilai tanah dapat dilakukan negosiasi selama tidak melebihi nilai tanah yang telah ditetapkan oleh appraisal. Sebaiknya ganti kerugian tidak hanya mengakomodir nilai ekonomis dari tanah, tetapi juga dampak dari adanya pembangunan bagi kepentingan umum (Mujiburohman dan Kusmiarto 2014).

Perangkat desa merupakan pejabat satuan terkecil yang sangat dekat dengan masyarakat, sehingga dapat dikatakan kesuksesan dalam membantu negosiasi nilai tanah ke masyarakat tidak 
terlepas dari para perangkat desa. Berdasarkan temuan di lapangan pada kedua pengadaan tanah skala kecil baik dengan dan tanpa menggunakan penetapan lokasi, maka dapat di kategorikan menjadi 13 indikator dalam membandingkan pengadaan tanah skala kecil dengan dan tanpa penetapan lokasi.

Berdasarkan Tabel 2, terdapat 13 indikator dari hasil perbandingan pengadaan tanah skala kecil. Pada bagian dengan simbol "_" memiliki arti bahwa pelaksanaan berdasarkan indikator tersebut mengarah ke pelaksanaan yang kurang baik. Berbanding terbalik pada simbol "+" memiliki arti bahwa pelaksanaan indikator ke arah yang lebih baik. Selanjutnya, 13 indikator tersebut dimasukkan ke dalam matriks SWOT untuk mendapatkan strategi pelaksanaannya.

Tabel 2. Perbandingan Pengadaan Tanah Skala Kecil

\begin{tabular}{lccc}
\hline No. & Penetapan Lokasi & Indikator & Tanpa Penetapan Lokasi \\
\hline 1. & - & Waktu Pelaksanaan & + \\
2. & - & Waktu Pembangunan & + \\
3. & - & Biaya Pelaksanaan & + \\
4. & + & Konsinyasi & - \\
5. & - & Pendekatan Sosial & + \\
6. & + & Potensi Merugikan Negara & - \\
7. & + & Tingkat Keberhasilan & - \\
8. & + & Kelengkapan Dokumen Perencanaan & + \\
9. & - & Koordinasi Panitia & + \\
10. & - & Potensi Adanya Tanah Sisa & - \\
11. & + & Transparansi Nilai Ganti Rugi & - \\
12. & + & Partisipasi Masyarakat & + \\
13. & - & &
\end{tabular}

Sumber: Pengolahan Data Primer, 2020.

2. Hasil analisis SWOT Pengadaan Tanah dengan Penetapan Lokasi

Identifikasi terhadap hasil pelaksanaan pelebaran Jalan Padjajaran sebagai pendukung pembangunan Underpass di Simpang Empat Jalan Kaliurang di dalam Keputusan Gubernur Daerah Istimewa Yogyakarta telah menemukan beberapa temuan. Temuan-temuan tersebut dapat dikelompokkan menjadi 2 kategori yaitu temuan-temuan yang bersifat internal yaitu temuantemuan dari dalam tim pelaksana pengadaan tanah yaitu kekuatan-kekuatan (strength) dan kelemahan-kelemahan (weaknesses), serta temuan-temuan yang bersifat eksternal yaitu temuantemuan yang berasal dari lingkungan luar tim pelaksana pengadaan tanah yaitu kesempatankesempatan (opportinities) dan tantangan-tantangan (treaths). Temuan tersebut dianalisis dengan menggunakan metode SWOT (strengths, weaknesses, oppurtunities, dan threats). Analisis SWOT merupakan analisis penyusunan suatu strategi untuk diterapkan pada masa mendatang dengan mengidentifikasi berbagai faktor secara sistematis (Rangkuti 2009).

Tabel 3. Matrik SWOT Pengadaan Tanah Skala Kecil dengan Penetapan Lokasi Strength (S) Weakness (W)

1. Dapat dilakukan konsinyasi.

1. Waktu pelaksanaan

2. Lokasi tidak berpindahpengadaan tanah cenderung pindah. lama. 
Opportunities (0)

1. Nilai ganti rugi ditetapkan 1 oleh appraisal sehingga tidak berpotensi merugikan negara.
3. Dokumen
perencanaan lengkap.
4. Kelengkapan pengadaan tanah.
5. Transparansi nilai ganti rugi.
perizinan

Threats $(T)$

1. Kurang terjalin hubungan 1. Perlunya adanya koordinasi sosial yang baik terhadap dengan kantor pertanahan masyarakat terkena pengadaan tanah.

Perlunya keterbukaan
informasi mengenai
penghitungan nilai tanah.
untuk menyusun daftar nominatif sementara yang 2 .

2. Koordinasi antar panitia pengadaan tanah yang kurang baik. terdapat dalam dokumen perencanaan.

2. Perlu adanya perlibatan masyarakat.

1. Perlu adanya perencanaan anggaran yang detail dalam dokumen perencanaan.

2. Penyederhanaan peraturan pengadaan tanah mengenai penetapan lokasi dapat dilimpahkan ke Bupati atau Walikota selaku kepala daerah setempat.

1. Perlu adanya evaluasi secara berkala mengenai pelaksanaan pengadaan tanah.

2. Waktu

pembangunan

3. Biaya pelaksanaan pengadaan tanah besar.

Optimalisasi aplikasi Sistem Informasi Pengadaan Tanah secara online sehingga dapat mendukung upaya percepatan pengadaan tanah.

3. Potensi adanya tanah sisa

4. Kurangnya partisipasi masyarakat.

Sumber: Pengolahan Data Primer, 2020

3. Hasil analisis SWOT pengadaan tanah skala kecil tanpa menggunakan Penetapan Lokasi Identifikasi terhadap hasil pelaksanaan penambahan lahan untuk pembangunan Jalan dan Jembatan Lemah Abang telah menemukan beberapa temuan. Berikut dapat dijelaskan temuantemuan mana saja yang bisa dikelompokkan pada ketegori-kategori tersebut.

Tabel 4. Matrik SWOT Pengadaan Tanah tanpa Penetapan Lokasi

\begin{tabular}{|c|c|c|}
\hline & Strength (S) & Weakness (W) \\
\hline & $\begin{array}{l}\text { 1. Waktu pelaksanaan } \\
\text { pengadaan tanah relatif } \\
\text { lebih cepat. } \\
\text { 2. Waktu pembangunan } \\
\text { lebih cepat. } \\
\text { 3. Biaya pelaksanaan } \\
\text { pengadaan tanah yang } \\
\text { tidak banyak. }\end{array}$ & $\begin{array}{l}\text { 1. Tidak dapat dilakukan } \\
\text { konsinyasi. } \\
\text { 2. Lokasi pengadaan tanah } \\
\text { dapat berpindah-pindah. } \\
\text { 3. Dokumen perencanaan } \\
\text { yang tidak lengkap. } \\
\text { 4. Perizinan yang tidak } \\
\text { lengkap. }\end{array}$ \\
\hline \multicolumn{3}{|l|}{ Opportunities (0) } \\
\hline $\begin{array}{l}\text { 1. Panitia pelaksana } \\
\text { tanah dapat mengadaan } \\
\text { pendekatan secara personal }\end{array}$ & $\begin{array}{l}\text { 1. Penguatan kerjasama } \\
\text { panitia pengadaan tanah } \\
\text { dan aparat desa. }\end{array}$ & $\begin{array}{l}\text { 1. Perlu adanya pendataan } \\
\text { nominatif sementara } \\
\text { sebelum dilakukan } \\
\text { pengadaan tanah dengan }\end{array}$ \\
\hline
\end{tabular}


kepada para pemilik bidang 2. Perlu adanya dibantu oleh aparat desa

tanah. $\quad$ penunjukan secara resmi

2. Aparat desa turut mendukung proses pengadaan tanah.

3. Tidak adanya potensi terdapat tanah sisa.

4. Adanya partisipasi aktif masyarakat dalam proses pengadaan tanah.

Threats ( $T$ )

1. Negosiasi nilai ganti rugi berpotensi merugikan negara.

2. Tidak adanya transparansi nilai ganti rugi. pihak pemerintah desa dalam kepanitiaan pengadaan tanah. dan masyarakat. partisipasi

(1)

1. Perlu adanya Sistem Informasi Pertanahan yang lengkap.

2. Perlu adanya Sistem Informasi Pengadaan Tanah untuk mengakomodir kegiatan pengadaan tanah.

Sumber: Pengolahan Data Primer, 2020

\section{G. Kesimpulan}

Pengadaan tanah skala kecil untuk kepentingan umum dapat dilakukan dengan dan tanpa penetapan lokasi. Kelebihan proses pengadaan tanah dengan menggunakan penetapan lokasi yaitu: 1) Dapat dilakukan konsinyasi, 2) Lokasi tidak berpindah-pindah, 3) Dokumen perencanaan yang lengkap, 4) Kelengkapan perizinan pengadaan tanah, 5) Transparansi nilai ganti rugi, 6) Nilai ganti rugi ditetapkan oleh appraisal sehingga tidak berpotensi merugikan negara

Kelemahan proses pengadaan tanah yang menggunakan penetapan lokasi yaitu: 1) Waktu pelaksanaan pengadaan tanah cenderung lama, 2) Waktu pembangunan cenderung lama, 3) Biaya pelaksanaan pengadaan tanah besar, 4) Kurang terjalin hubungan sosial yang baik terhadap masyarakat terkena pengadaan tanah, 5) Koordinasi antar panitia pengadaan tanah yang kurang baik, 6) Potensi terdapat tanah sisa, 7) Kurangnya partisipasi masyarakat.

Kelebihan proses pengadaan tanah tanpa menggunakan penetapan lokasi yaitu: 1) Waktu pelaksanaan pengadaan tanah relatif lebih cepat, 2) Waktu pembangunan lebih cepat, 3) Biaya pelaksanaan pengadaan tanah tidak banyak, 4) Panitia pelaksana pengadaan tanah dapat melakukan pendekatan secara personal kepada para pemilik bidang tanah, 5) Aparat desa turut mendukung proses pengadaan tanah, 6) Tidak adanya potensi terhadap tanah sisa, 7) Adanya partisipasi aktif masyarakat dalam proses pengadaan tanah.

Kelemahan proses pengadaan tanah tanpa menggunakan penetapan lokasi yaitu: 1) Tidak dapat dilakukan konsinyasi, 2) Lokasi pengadaan tanah dapat berpindah-pindah, 3) Dokumen perencanaan yang tidak lengkap, 4) Perizinan yang tidak lengkap, 5) Negosisasi nilai ganti rugi berpotensi merugikan Negara, 6) Tidak adanya transparansi nilai ganti rugi. 


\section{Rekomendasi}

1. Diperlukan penguatan sistem informasi pertanahan dengan melakukan inventarisasi data penguasaan, pemilikan, penggunaan dan pemanfaatan tanah di wilayah yang menjadi objek pengadaan tanah sehingga menghasilkan informasi yang bermanfaat sebagai daftar nominatif sementara pengadaan tanah.

2. Perkuat koordinasi yang kuat antara panitia pengadaan tanah dan aparat desa sehingga proses pengadaan tanah dapat berlangsung dengan baik.

3. Perlu dilakukan optimalisasi Aplikasi Informasi Pengadaan Tanah berbasis online yang dapat mengakomodir seluruh tahapan pengadaan tanah dan dapat diakses oleh para panitia pengadaan tanah dan dipantau oleh KPPIP bahkan oleh Presiden.

\section{Daftar Pustaka}

Dulmuzi, D., Sinulingga, S., \& Pujangkoro, S. (2019). Analisis Penetapan Nilai Pengganti Wajar dalam Pengadaan Tanah untuk Kepentingan Umum di Kota Lhokseumawe. (JMK) Jurnal Manajemen dan Kewirausahaan, 4(2), 102-115.

Makarauw, V. (2012). Penduduk, perumahan pemukiman perkotaan dan pendekatan kebijakan. Sabua: Jurnal Lingkungan Binaan dan Arsitektur, 3(1), 53-57.

Mujiburohman, D. A., \& Kusmiarto, K. (2014). Aspek Hak Asasi Manusia Dalam Pengadaan Tanah. Bhumi: Jurnal Agraria dan Pertanahan, $40 \quad$ (13), 621-632. http://jurnalbhumi.stpn.ac.id/index.php/JB/article/view/193

Naryana, A., Sudibyanung, S., \& Pinuji, S. (2020). Faktor Pendorong dan Penghambat Keberhasilan Pengadaan Tanah Skala Kecil di Kabupaten Karanganyar (Studi Pembangunan Sistem Penyediaan Air Minum Regional WOSUSOKAS dan Jembatan Kragan). Tunas Agraria, 3(1), 163-179.

Prasetyo, P. K., Christine, R. V., \& Sudibyanung, S. (2020). Implementasi Asas Keterbukaan pada Pengadaan Tanah bagi Pembangunan untuk Kepentingan Umum: Antara Harapan dan Kenyataan. BHUMI: Jurnal Agraria dan Pertanahan, 6(1), 15-27.

http://jurnalbhumi.stpn.ac.id/JB/issue/view/32

Putri, J. A. A. (2017). Pelaksanaan Pengadaan Tanah Skala Kecil (Studi Kasus Pembebasan Lahan Bundaran Dolog di Surabaya) (Tesis). Universitas Brawijaya. Malang http://hukum.studentjournal.ub.ac.id/index.php/hukum/article/view/2367

Rangkuti, F. (2009). Analisis SWOT Teknik Membedah Kasus Bisnis, cetakan 16. Jakarta: Gramedia Pustaka Utama.

Rohaedi, E., Insan, I. H., \& Zumaro, N. (2019). Mekanisme Pengadaan Tanah Untuk Kepentingan Umum. Pakuan Law Review, 5(2), 198-220

https://journal.unpak.ac.id/index.php/palar/article/view/1192/0

Sudirman, S. (2014). Pembangunan Jalan Tol Di Indonesia: Kendala Pembebasan Tanah Untuk Pembangunan Bagi Kepentingan Umum Dan Gagasan Upaya Penyelesaiannya. BHUMI: Jurnal Agraria dan Pertanahan, (40), 522-544. 
http://pppm.stpn.ac.id/wp-content/uploads/2017/09/Bhumi-Oktober-2014.pdf

Tohari, A. (2014). Pengadaan tanah untuk siapa, peniadaan tanah dari siapa: pengadaan tanah, alokasi tanah, dan konflik agraria. BHUMI: Jurnal Agraria dan Pertanahan, (40), 563-575. http://pppm.stpn.ac.id/wp-content/uploads/2017/09/Bhumi-Oktober-2014.pdf

Wafa, MNHE, Subiyanto, S \& Amarrohman, FJ. (2017). Analisis Penguasaan, Pemilikan, Penggunaan dan Pemanfaatan Tanah (P4T) Berdasarkan Sebaran Bidang Tanah Untuk Kegiatan Normalisasi Sungai Menggunakan SIG Tahun 2016 (studi kasus : kali beringin kel. mangkang wetan), Jurnal Geodesi Undip, 6 (1), 169-178. 